\title{
Levobunolol compared with timolol: a four-year study
}

\author{
ORNA GEYER, ${ }^{1}$ MOSHE LAZAR, ${ }^{1}$ GARY D NOVACK, ${ }^{23}$ DAVID SHEN ${ }^{3}$ \\ AND CHERYL Y ETO ${ }^{3}$
}

From the 'Department of Ophthalmology, Ichilove Medical Center, Sackler School of Medicine, University of Tel Aviv, Israel; the ${ }^{2}$ University of California, Irvine, California, USA; and the ${ }^{3}$ Department of Clinical

Research, Allergan Pharmaceuticals, Irvine, California, USA

SUMMARY Fifty-one patients with raised intraocular pressure (IOP) were treated for up to four years with one of three ophthalmic solutions: $0 \cdot 5 \%$ levobunolol, $1 \%$ levobunolol, or $0.5 \%$ timolol. The study was conducted as a double-masked, randomised trial in which medications were administered twice daily to both eyes. Levobunolol and timolol were equally effective in reducing overall mean IOP; reductions were greater than $8.8 \mathrm{mmHg}$ in all three treatment groups. The study showed levobunolol to be as safe and effective as timolol in the long-term control of raised IOP.

Glaucoma is a chronic disease, generally requiring a lifetime of treatment. Most evaluations of new agents, however, are of relatively limited durations. In the present report we describe our findings in a four-year, double-masked comparison of levobunolol, a new $\beta_{1} / \beta_{2}$-adrenoceptor antagonist, and timolol. This is a follow-up to our previous one-year report of this comparison. ${ }^{1}$

\section{Subjects and methods}

As detailed previously, ${ }^{1}$ this was a randomised, double-masked comparison of three treatments: $0.5 \%$ levobunolol, $1 \%$ levobunolol, or $0.5 \%$ timolol. All were administered twice daily into both eyes. Patients with chronic open-angle glaucoma or ocular hypertension characterised by untreated IOP values of $23 \mathrm{mmHg}$ or higher in both eyes were considered for the study. Excluded from participation were patients with contraindications to the topical or systemic use of beta blockers, those with secondary or narrow-angle glaucoma or aphakia, and those who had used systemic beta blockers within the three months immediately preceding the study.

The study consisted of 35 visits including a baseline examination. After the baseline examination and as close as possible to $9 \mathrm{am}$ the patients received a single drop of the test medication into each eye. They were

Correspondence to Dr Gary D Novack, Nelson Research, 1001 Health Sciences Road West, California 92715, USA. then instructed to administer a single drop of the study medication into each eye twice daily ( 9 am and $9 \mathrm{pm}$ ) for the duration of the study. The cup-disc ratio was measured subjectively with a direct ophthalmoscope and visual fields by Goldmann kinetic perimetry.

IOP values for right and left eyes were averaged for analysis. Owing to differences at baseline an analysis of covariance model (ANCOVA) was used to analyse mean changes of IOP from baseline. ${ }^{2}$ Withingroup changes from baseline were tested for significance with the paired $t$ test. Overall mean changes from baseline were tested by analysis of variance (ANOVA) for repeated measures design. ${ }^{3}$ KaplanMeier survival curves were used to evaluate time to treatment failure due to uncontrolled IOP. ${ }^{4}$ Survival curves were compared among the groups by the logrank method. ${ }^{5}$ Results were considered statistically significant if $\mathrm{p}$ values were $\leqslant 0 \cdot 05$.

\section{Results}

Fifty-one patients participated in the study. One patient was diagnosed as having ocular hypertension; the rest had open-angle glaucoma. Other demographic characteristics are presented in Table 1.

As shown in Fig. 1, the cumulative probability of successful control of IOP (life-table analysis) for four years was approximately $40 \%$ for each treatment group. There was no significant difference among 


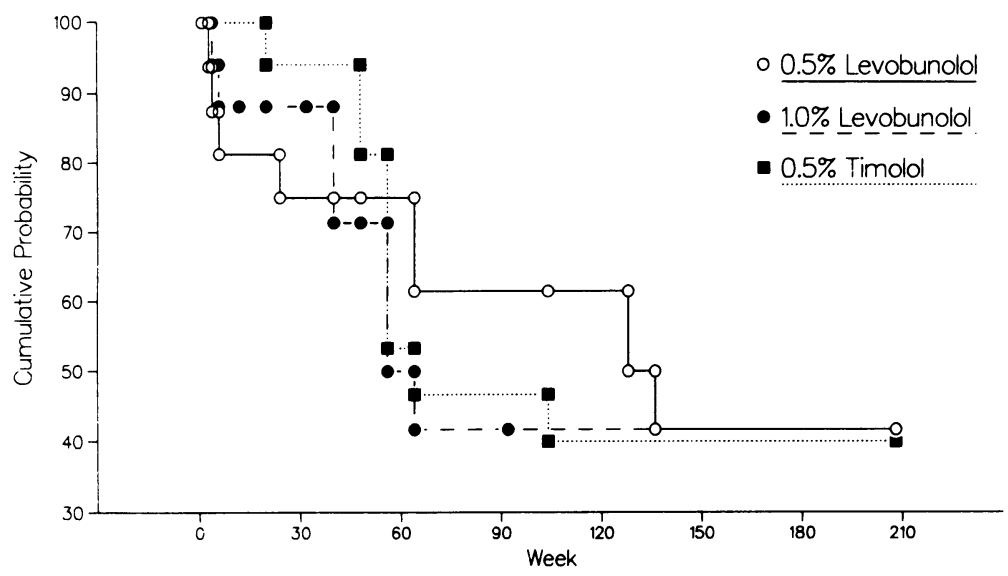

Fig. 1 Cumulative probability of successful control of IOP approximately $40 \%$ in each treatment group.

groups. Most of the efficacy failures occurred within the first two years of the study.

The status of all the patients at the end of the study is shown in Table 2. In addition to the patients whose treatment was terminated owing to inadequate control of IOP, approximately $8 \%$ had their treatment terminated for drug-related adverse effects. These were in the two levobunolol groups and included three reports of topical allergies to levobunolol and one report of dyspnoea. All adverse effects occurred after approximately one year of treatment.

As shown in Fig. 2, there was a significant decrease of mean IOP from baseline in all three treatment groups throughout the four years of the study. Overall, the mean decrease in IOP was $9.5 \mathrm{mmHg}$, $9.6 \mathrm{mmHg}$, and $8.8 \mathrm{mmHg}$ in the $0.5 \%$ levobunolol, $1 \%$ levobunolol and $0.5 \%$ timolol groups, respectively. There were no significant differences among the groups.

Table 1 Studypopulation*

\begin{tabular}{|c|c|c|c|}
\hline Variable & $\begin{array}{l}0.5 \% \\
\text { Levobunolol } \\
(n=17)\end{array}$ & $\begin{array}{l}1 \% \\
\text { Levobunolol } \\
(n=17)\end{array}$ & $\begin{array}{l}0 \cdot 5 \% \\
\text { Timolol } \\
(n=17)\end{array}$ \\
\hline \multicolumn{4}{|l|}{ Age (years) } \\
\hline Mean \pm SD & $70 \cdot 9 \pm 6 \cdot 9$ & $70 \cdot 8 \pm 9 \cdot 1$ & $69 \cdot 1 \pm 6 \cdot 7$ \\
\hline \multicolumn{4}{|l|}{ Sex } \\
\hline Male & 10 & 10 & 12 \\
\hline Female & 6 & 7 & 5 \\
\hline Not reported & 1 & 0 & 0 \\
\hline \multicolumn{4}{|l|}{ Iris colour } \\
\hline Blue & 0 & 1 & 3 \\
\hline Green & 6 & 7 & 6 \\
\hline Brown & 11 & 9 & 8 \\
\hline \multicolumn{4}{|l|}{ Glaucoma diagnosis } \\
\hline Open-angle glaucoma & $16(94 \%)$ & $17(100 \%)$ & $17(100 \%)$ \\
\hline Ocular hypertension & $1(6 \%)$ & $0(0 \%)$ & $0(0 \%)$ \\
\hline
\end{tabular}

*No significant differences among the groups were noted.
Table 2 Status of patients at end of four years

\begin{tabular}{ccccc}
\hline & $\begin{array}{l}0 \cdot 5 \% \\
\text { Levobunolol }\end{array}$ & $\begin{array}{l}1 \% \\
\text { Levobunolol }\end{array}$ & $\begin{array}{l}0 \cdot 5 \% \\
\text { Timolol }\end{array}$ & Total \\
\hline $\begin{array}{c}\text { Successfully } \\
\text { completed }\end{array}$ & $4(23 \%)$ & $4(24 \%)$ & $6(35 \%)$ & $14(27 \%)$ \\
$\begin{array}{c}\text { Terminated: } \\
\text { Inadequate } \\
\text { control of }\end{array}$ & $7(41 \%)$ & $7(41 \%)$ & $9(53 \%)$ & $23(45 \%)$ \\
$\begin{array}{c}\text { IOP } \\
\text { Terminated: } \\
\text { Drug-related } \\
\text { adverse } \\
\text { experience }\end{array}$ & $3(18 \%)$ & $1(6 \%)$ & $0(0 \%)$ & $4(8 \%)$ \\
$\begin{array}{c}\text { Discontinued: } \\
\text { Not drug } \\
\text { related }\end{array}$ & $3(18 \%)$ & $5(29 \%)$ & $2(12 \%)$ & $10(20 \%)$ \\
\begin{tabular}{c} 
Total \\
\hline
\end{tabular} & 17 & 17 & 16 & 50 \\
\hline
\end{tabular}

As shown in Table 3, there were reports of clinically significant increases in cup/disc ratio $(\geqslant 0 \cdot 2)$ and in progressive visual field loss in approximately one-half of the patients. The treatment groups were similar in this respect.

Overall, the mean changes in pupil size were less than $+\mathbf{0 . 2 5} \mathrm{mm}$. Mean decreases in Schirmer tests were less than $2.5 \mathrm{~mm}$. No changes were seen in the

Table 3 Cup-disc ratio increases and visual field losses

\begin{tabular}{llll}
\hline & $\begin{array}{l}0 \cdot 5 \% \\
\text { Levobunolol }\end{array}$ & $\begin{array}{l}1 \% \\
\text { Levobunolol }\end{array}$ & $\begin{array}{l}0 \cdot 5 \% \\
\text { Timolol }\end{array}$ \\
\hline $\begin{array}{l}\text { Cup-disc ratios } \\
\text { increase } \leqslant 0 \cdot 2\end{array}$ & $7(44 \%)$ & $9(53 \%)$ & $11(65 \%)$ \\
$\begin{array}{c}\text { Glaucomatous visual } \\
\text { field losses* }\end{array}$ & $6(38 \%)$ & $3(18 \%)$ & $10(59 \%)$ \\
\hline
\end{tabular}

*Defined as Bjerrum's scotoma, nasal step, generalised constriction, or enlarged blind spot not present at baseline examination. 


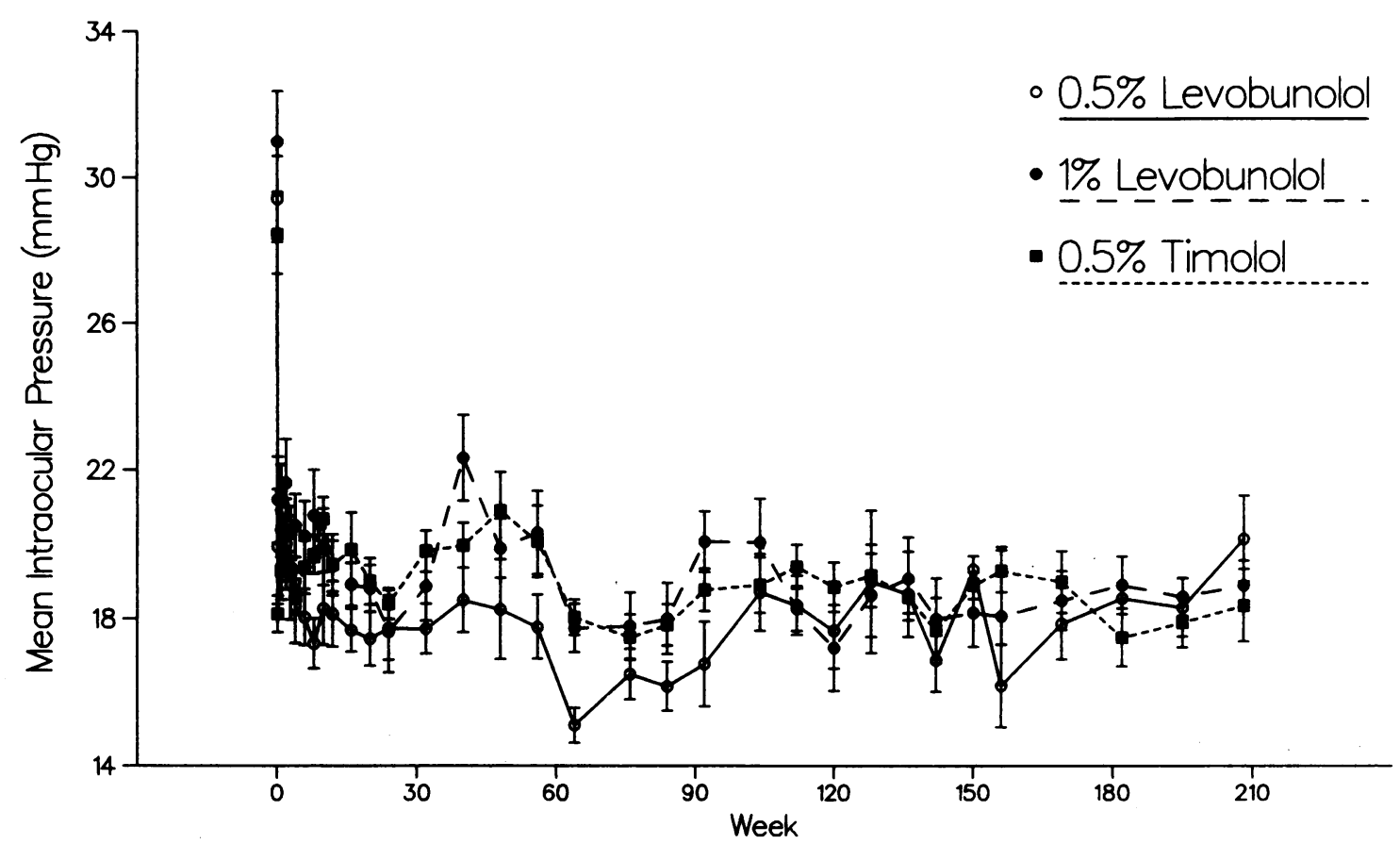

Fig. 2 Significant decrease of mean IOP in each treatment group.

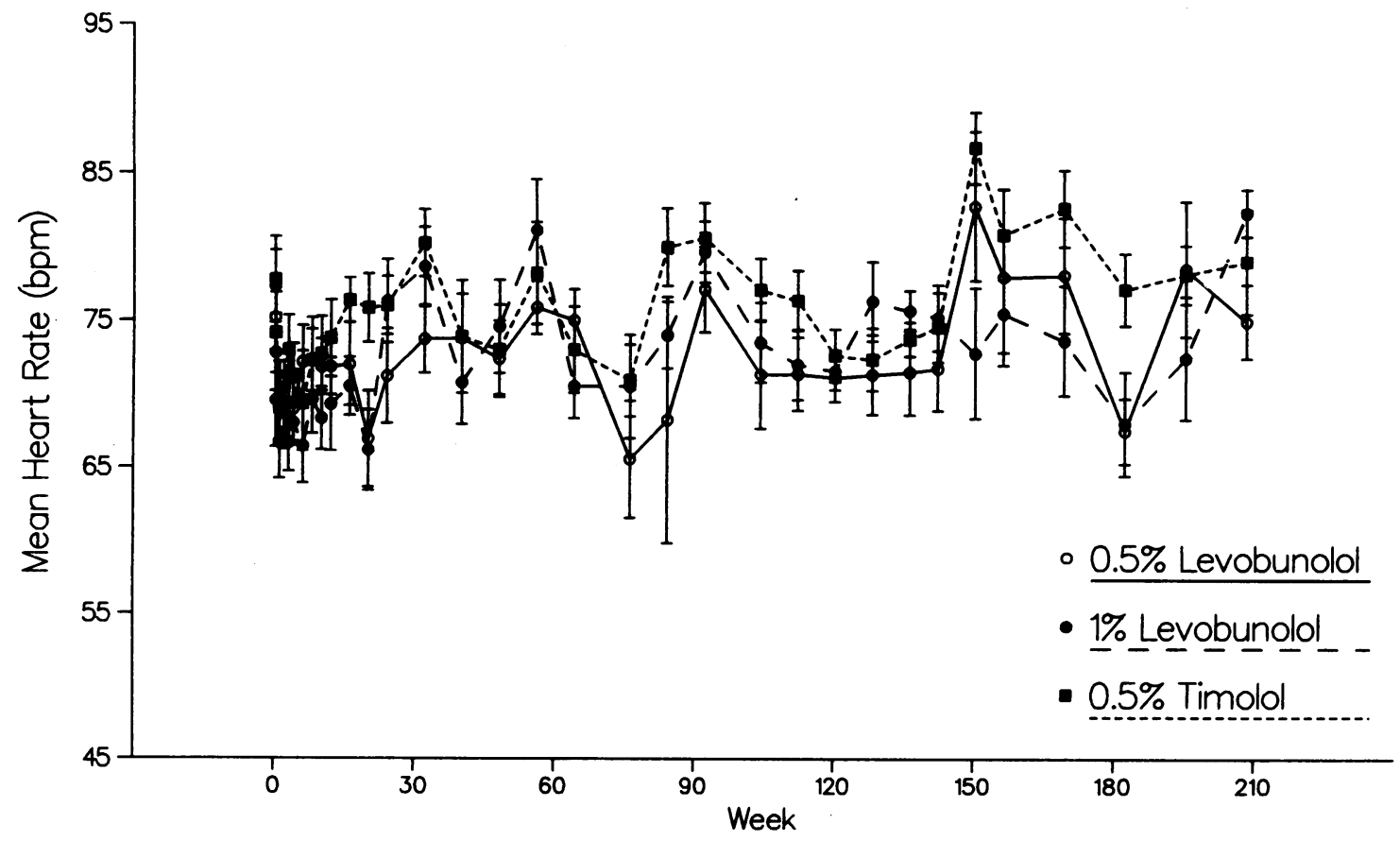

Fig. 3 Mean heart rate decreased in first week of therapy, but decreases did not subsequently change. 


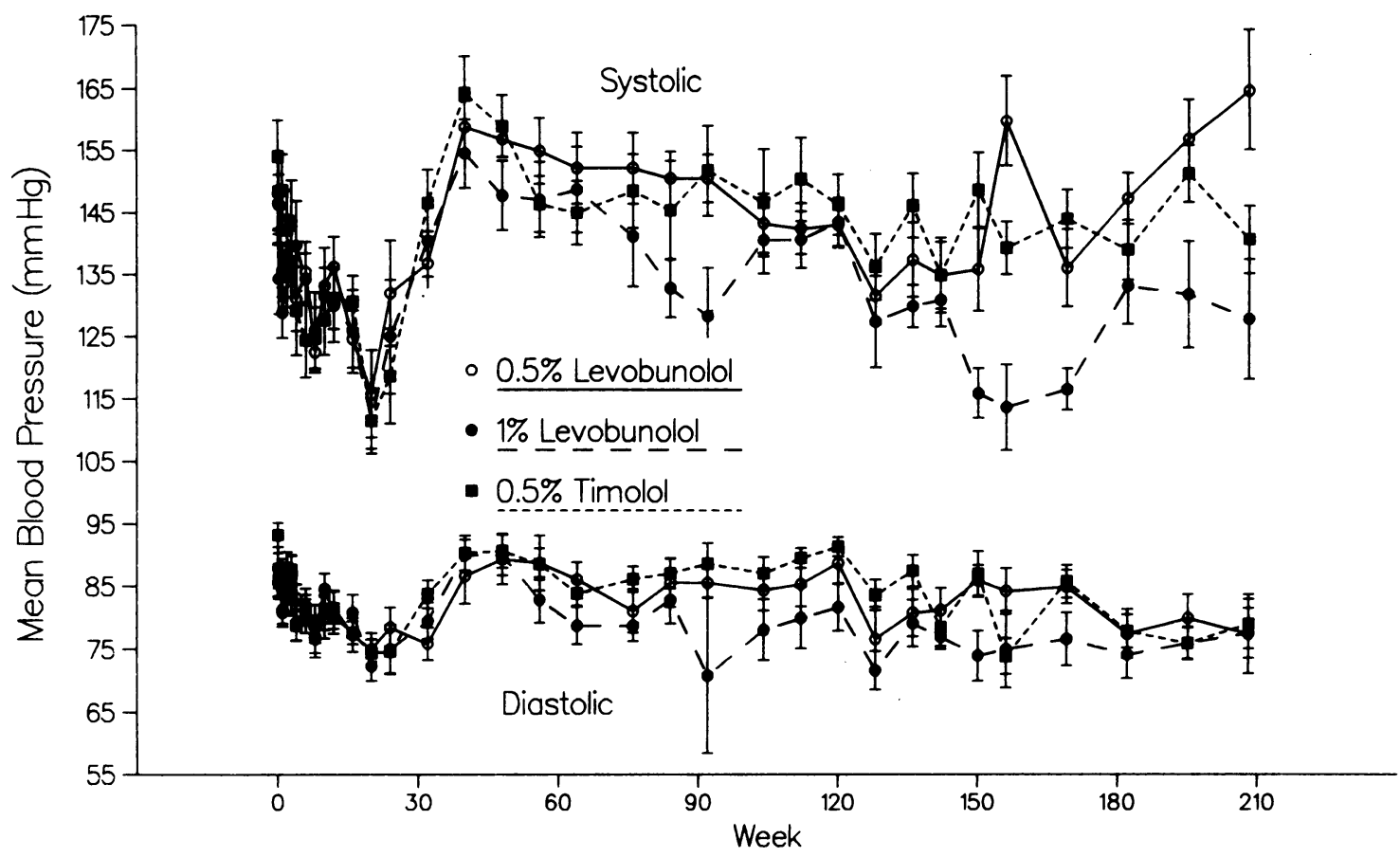

Fig. 4 Decreases in mean systolic and diastolic blood pressure in each treatment group.

blink test. None of these changes was of clinical or statistical significance.

While decreases in mean heart rate of 5-10 bpm were observed with the first week of therapy (Fig. 3), these decreases did not change significantly over time. There were decreases in mean systolic and diastolic blood pressure in all treatment groups (Fig. 4). There were no significant differences among groups in overall mean changes in heart rate or blood pressure (Table 4). In general, the incidence of clinically significant biomicroscopic and ophthalmoscopic findings were similar among the groups.

Patients' complaints were few, numbering only three. One patient using $0.5 \%$ timolol had epiphora at one visit. Another using $0.5 \%$ levobunolol reported unilateral trigeminal irritation, which

Table 4 Overall mean changes in cardiovascular variables

\begin{tabular}{lllc}
\hline & $\begin{array}{l}0.5 \% \\
\text { Levobunolol }\end{array}$ & $\begin{array}{l}1 \% \\
\text { Levobunolol }\end{array}$ & $\begin{array}{l}0.5 \% \\
\text { Timolol }\end{array}$ \\
\hline Heart rate (bpm) & -1.3 & -3.9 & -1.3 \\
$\begin{array}{l}\text { Systolic blood pressure } \\
\text { (mmHg) }\end{array}$ & 1.0 & -5.0 & -11.6 \\
$\begin{array}{c}\text { Diastolic blood } \\
\text { pressure (mmHg) }\end{array}$ & -0.4 & -3.9 & -6.7 \\
\hline
\end{tabular}

There were no significant differences among groups. resolved within one month. The third, who used $1 \%$ levobunolol, reported dizziness at three visits.

\section{Discussion}

In this study levobunolol was as safe and effective as timolol for the long-term treatment of raised IOP. The long-term efficacy failure rate of approximately $15 \%$ per year was not only similar for levobunolol and timolol in this study but similar to that in a twoyear study comparing the same treatments. ${ }^{b}$ Interestingly, most of the efficacy failures occurred in the first two years. Outside the treatment protocol we found that these patients could be controlled with the addition of pilocarpine or dipivefrin. The longterm safety profile of levobunolol was good and similar to that of timolol. The possible untoward effects of levobunolol seen here, decreased cardiovascular function and topical allergy, are similar to those reported previously for both timolol and levobunolol. ${ }^{67}$

Of some concern in the present study is that, in spite of well maintained IOP reductions, some patients in each treatment group appeared to show additional visual field and nerve head deterioration. While manual Goldmann visual fields and subjective ophthalmoscopic estimations of cup-disc ratio are standard for clinical practice, they are quite vari- 
able. ${ }^{89}$ Newer research techniques might have more objectively tracked these changes, if indeed they represent true glaucomatous progression.

However, as is well known, medical or surgical ocular hypotensive therapy may not necessarily halt the glaucomatous process. Some studies suggest that treatment retards the progression rate of glaucoma, ${ }^{1011}$ others do not. ${ }^{1213}$ Testing these hypotheses requires evaluation of a group of patients who receive no treatment and long-term follow-up with automated perimetry, as is being undertaken by Alexander and associates. ${ }^{14}$ The present study was conducted not to answer the larger question of the efficacy of treatment on the disease itself but to compare a new ocular hypotensive agent, levobunolol, with a currently accepted one, timolol. In that regard we found both treatments equivalent.

As in other controlled studies, with neither levobunolol nor timolol did we see evidence of punctate keratitis, dry eye, corneal anaesthesia, or other ocular findings previously reported for timolol. ${ }^{67}$ This suggests that such clinical reports may be relatively rare. Indeed, the frequency of ophthalmic examination in our study, 35 visits over four years, might tend to exaggerate the 'real' incidence.

Our four-year results support the trends we observed in the first year ${ }^{1}$ as well as observations from other studies. ${ }^{6}$ Levobunolol is as safe and effective as timolol for the long-term control of IOP in patients with glaucoma.

The authors gratefully acknowledge the research consultation of Efraim Duzman, MD, and the editorial assistance of Michele Vivirito and Mary-Jane Branin.

\section{References}

1 Geyer O, Lazar M, Novack GD, Lue JC, Duzman E. Levobunolol compared with timolol for the control of elevated intraocular pressure. Ann Ophthalmol 1986; 18: 289-92.

2 Neter J, Wasserman W. Applied linear statistical models. Home Wood, Ill: Richard D Irwin, Inc, 1974: 685-727.

3 Winer BJ. Statistical principles in experimental design. New York: McGraw-Hill, 1971: 518-29.

4 Kaplan EL, Meier P. Nonparametric estimation from incomplete observations. J Am Statistical Assoc 1958; 53: 457-81.

5 Peto R, Pike MC, Armitage P, et al. Design and analysis of randomized clinical trials requiring prolonged observation of each patient. Part II. Br J Cancer 1976; 35: 1-39.

6 Levobunolol Study Group. Levobunolol: a beta-adrenergic antagonist effective in the long-term treatment of glaucoma. Ophthalmology 1985; 92: 1271-6.

7 VanBuskirk EM. Adverse reactions from timolol administration. Ophthalmology 1980; 87: 447-50.

8 Schwartz JT. Methodologic differences and measurement of cup-disc ratio: an epidemiologic assessment. Arch Ophthalmol 1976; 94: 1101-5.

9 Johnson CA, Keltner JL. Comparative evaluation of the Autofield-I, CFA-120, and Fieldmaster Model 101-PR automated perimeters. Ophthalmology 1980; 87: 777-84.

10 Becker B, Morton WR. Topical epinephrine in glaucoma subjects. Am J Ophthalmol 1966; 62: 272-7.

11 Eddy EM, Sanders LE, Eddy JF. The value of screening for glaucoma with tonometry. Surv Ophthalmol 1983; 28: 194-205.

12 Holmin C, Krakau CET. Visual field decay in normal subjects and in cases of chronic glaucoma. Graefes Arch Clin Exp Ophthalmol 1980; 213: 291-8.

13 Bengtsson B. Manifest glaucoma in the aged 1: Occurrence nine years after a population survey. Acta Ophthalmol (Kbh) 1981; 59: 321-31.

14 Alexander DW, Berson R, Epstein DL. A clinical trial of timolol and epinephrine in the treatment of primary open-angle glaucoma. Ophthalmology 1988; 95: 247-51.

Accepted for publication 24 September 1987. 